\title{
Reduced insulin binding to human fat cells following beta-adrenergic stimulation - experimental evidence and studies in patients with a phaeochromocytoma
}

\author{
P. Lönnroth ${ }^{1}$, C. Wesslau ${ }^{1}$, G. Stenström ${ }^{1}$, L.-E. Tisell ${ }^{2}$ and U. Smith ${ }^{1}$ \\ Departments of ${ }^{1}$ Medicine II and ${ }^{2}$ Surgery I, Sahlgren's Hospital, University of Göteborg, Göteborg, Sweden
}

\begin{abstract}
Summary. The effect of $\beta$-adrenergic stimulation on insulin binding was studied in human fat cells in vitro. Isoproterenol rapidly $(\sim 5 \mathrm{~min})$ reduced insulin binding through a $\beta$-adrenergic and dose-dependent mechanism. The reduced binding was enhanced by the addition of adenosine deaminase and was also elicited by the addition of dibutyryl cAMP. This effect was due to a decreased number of binding sites. The reduction was rapidly reversed by propranolol $\left(\mathrm{t}^{1 / 2} \sim 10 \mathrm{~min}\right)$ and other $\beta$-adrenoreceptor blocking agents. Insulin binding was also measured in fat cells from 6 patients with a phaeochromocytoma. A significant negative correlation between
\end{abstract}

tracer binding and the log value of total urinary catecholamine excretion was found $(r=-0.821, p<0.05)$. Mean tracer insulin binding was reduced about $30 \%$ as compared to cells from 16 carefully matched control subjects. Decreased insulin binding was again mainly attributable to a decreased number of binding sites. Thus, $\beta$-adrenergic stimulation, both in vitro and in vivo, leads to a decreased number of binding sites for insulin in human fat cells.

Key words: Insulin resistance, insulin receptors, catecholamines, $\beta$-adrenergic receptors, phaeochromocytoma.
It is well known that infusion of catecholamines rapidly leads to a marked peripheral insulin resistance $[1,2]$. We have recently found that this is due to both a marked reduction of the maximal effect of insulin on peripheral glucose uptake combined with a rightward shift in the dose-response curve [3]. These findings strongly suggest that catecholamines produce insulin resistance by exerting effects at both the receptor and postreceptor level. Due to the presence of spare receptors, a moderate reduction of the number of insulin binding sites only leads to a rightward shift in the dose-response curve without reducing the maximal effect of insulin (reduced sensitivity) whereas a reduced response in the presence of a supramaximal hormone concentration is attributed to postreceptor perturbations $[4,5]$.

Recently, we and others independently reported that $\beta$-adrenergic stimulation leads to a rapid reduction of insulin binding to rat adipocytes [6-8]. In addition, catecholamines were found to induce a marked inhibition of insulin-stimulated glucose transport in these cells [8-11]. The time course of both events is similar, suggesting that they may be elicited by the same mechanism [11]. These findings are likely to be of major importance for the well-known reduction of glucose tolerance seen in different clinical conditions with elevated catecholamine levels such as surgical stress, trauma and phaeochromocytoma.
In the present work, the effect of catecholamines on insulin binding to human fat cells in vitro was studied. In addition, insulin binding to fat cells from patients with a phaeochromocytoma was investigated and compared to that of a carefully matched control group.

\section{Subjects and methods}

For the studies of the effect of catecholamines added in vitro, $2-5 \mathrm{~g} \mathrm{bi}$ opsies of subcutaneous adipose tissue were obtained from the abdominal wall of 11 patients undergoing elective surgery for cholelithiasis. Patients were fasted overnight and initially given saline infusion during the operation. Biopsies were taken immediately after the induction of anaesthesia. None of the patients had clinical or laboratory findings of diabetes mellitus, icterus, liver disease or malignancy.

Adipose tissue biopsies were also obtained from six patients with a phaeochromocytoma (Table 1). Diagnosis was based on characteristic clinical findings, elevated catecholamine excretion in the urine and histological examination of excised tumours. Three patients clearly had preoperatively elevated fasting glucose levels (patients 2, 3, 5; Table 1). All but one patient, who probably had a malignant phaeochromocytoma (patient 2), had reduced fasting glucose levels after the tumour had been removed. Fasting insulin levels in four patients treated with phenoxybenzamine were $10 \pm 2 \mathrm{mU} / 1$ before and $12 \pm$ $3 \mathrm{mU} / 1$ after operation (means $\pm S E M$ ). Urinary excretion of adrenaline, noradrenaline and vanillylmandelic acid (VMA) was followed prior to surgery for 4-11 days in each patient. As shown in Table 1, the daily variation in urinary excretion was relatively small. Thus, mean values are considered representative for the catecholamine excretion. All patients were treated with an $\alpha$-blocking agent, phenoxybenzamine $20 \mathrm{mg} \times 3-4$, for at least 2 weeks before surgery. One patient 
Table 1. Clinical characteristics of the patients with a phaeochromocytoma and the control subjects

\begin{tabular}{|c|c|c|c|c|c|c|c|c|}
\hline \multirow{2}{*}{$\begin{array}{l}\text { Patient } \\
\text { No. }\end{array}$} & \multirow[t]{2}{*}{ Sex } & \multirow{2}{*}{$\begin{array}{l}\text { Age } \\
\text { (yrs) }\end{array}$} & \multirow{2}{*}{$\begin{array}{l}\text { Body mass } \\
\text { index }\end{array}$} & \multicolumn{2}{|c|}{ Fasting glucose } & \multicolumn{3}{|c|}{ Mean urinary catecholamine excretion ${ }^{\mathrm{a}}$} \\
\hline & & & & $\begin{array}{l}\text { Before } \\
\text { surgery }\end{array}$ & $\begin{array}{l}\text { After } \\
\text { surgery } \\
\text { ol/1) }\end{array}$ & Adrenaline & $\begin{array}{l}\text { Noradrenaline } \\
(\mathrm{nmol} / \mathrm{l} / 24 \mathrm{~h})\end{array}$ & $\begin{array}{l}\text { Vanillyl- } \\
\text { mandelic acid }\end{array}$ \\
\hline
\end{tabular}

Phaeochromocytoma patients

\begin{tabular}{|c|c|c|c|c|c|c|c|c|}
\hline 1 & $\mathrm{~F}$ & 79 & 21.6 & 4.6 & 3.7 & $100 \pm 6$ & $338 \pm 28$ & $25 \pm 1$ \\
\hline 2 & $\mathrm{~F}$ & 75 & 21.7 & 7.8 & 7.7 & $188 \pm 12$ & $1,313 \pm 93$ & $260 \pm 10$ \\
\hline 3 & $\mathrm{~F}$ & 65 & 29.6 & 7.8 & 4.3 & $295 \pm 71$ & $1,088 \pm 126$ & $178 \pm 7$ \\
\hline 4 & $\mathrm{M}$ & 59 & 24.0 & 5.3 & 5.2 & $1,260 \pm 50$ & $11,800 \pm 663$ & $202 \pm 12$ \\
\hline 5 & M & 38 & 26.8 & 8.2 & 4.4 & $53 \pm 6$ & $2,200 \pm 152$ & $297 \pm 76$ \\
\hline 6 & $\mathrm{~F}$ & 52 & 24.2 & 5.6 & 5.2 & $1,700 \pm 115$ & $2,667 \pm 145$ & $99 \pm 5$ \\
\hline Reference interval & - & - & - & - & - & $0-80$ & $70-480$ & $0-40$ \\
\hline $\begin{array}{l}\text { Mean } \\
\pm\end{array}$ & $4 \mathrm{~F} / 2 \mathrm{M}$ & 61 & 24.7 & 6.5 & 5.1 & & & \\
\hline SEM & & 6 & 1.3 & 0.6 & 0.6 & - & - & - \\
\hline \multicolumn{9}{|l|}{ Control subjects } \\
\hline $\begin{array}{l}\text { Mean } \\
\pm\end{array}$ & $6 \mathrm{~F} / 10 \mathrm{M}$ & 58 & 25.2 & 4.6 & & & & \\
\hline SEM & & 12 & 5.0 & 0.1 & & & & \\
\hline
\end{tabular}

${ }^{\text {a }}$ Results are means \pm SEM of 4-11 presurgical determinations (see Subjects and methods)

Table 2. Effect of isoproterenol and different $\beta$-adrenoceptor blocking agents on insulin binding

\begin{tabular}{|c|c|c|c|c|c|c|c|}
\hline $\begin{array}{l}\text { Additions } \\
\text { to medium }\end{array}$ & No additions & $\mathrm{KCN}$ & $\begin{array}{l}\mathrm{KCN} \\
+ \\
\text { ISO } \\
+\end{array}$ & $\begin{array}{l}\text { KCN } \\
+ \\
\text { ISO } \\
+ \\
\text { propranolol }\end{array}$ & $\begin{array}{l}\text { KCN } \\
+ \\
\text { ISO } \\
+ \\
\text { d-propranolol }\end{array}$ & $\begin{array}{l}\text { KCN } \\
+ \\
\text { ISO } \\
+ \\
\text { timolol }\end{array}$ & $\begin{array}{l}\mathrm{KCN} \\
+ \\
\mathrm{ISO} \\
+ \\
\text { metoprolol }\end{array}$ \\
\hline $\begin{array}{l}\text { Insulin binding } \\
\% \text { of control }\end{array}$ & 100 & $101 \pm 1$ & $83 \pm 2$ & $102 \pm 2$ & $89 \pm 4$ & $98 \pm 2$ & $97 \pm 1$ \\
\hline
\end{tabular}

Isolated human fat cells were incubated with $0.5 \mu \mathrm{mol} / 1$ isoproterenol (ISO) for $5 \mathrm{~min}$ with or without the addition of $10 \mu \mathrm{mol} / 1$ of the non-selective $\beta$-blocking agents propranolol and timolol or the relatively selective $\beta_{1}$-adrenoceptor blocking agent metoprolol. $2 \mathrm{mmol} / 1 \mathrm{KCN}$ was then added for another $5 \mathrm{~min}$ followed by the addition of $0.13 \mathrm{nmol} / 1^{125} \mathrm{I}$-insulin and the specific binding after 60 min was determined. The results are the means \pm SEM of two representative experiments

(patient 3) was given an intravenous injection $(5 \mathrm{mg})$ of the short-acting $\beta_{1}$-blocking agent, practolol, during induction of anaesthesia. A subcutaneous biopsy was obtained from the abdominal wall during the surgery immediately after induction of anaesthesia. Insulin binding data were compared to those obtained with abdominal fat cells from 16 control patients who had cholelithiasis surgery. The patients and the control subjects were matched for both age and body mass index (Table 1).

Informed consent was obtained from the patients. The study was approved by the Ethical Committee of the University of Gothenburg.

Fat cells were isolated in medium 199 with collagenase $(1.5 \mathrm{mg}$ / $\mathrm{ml})$ and bovine albumin $(4 \%, \mathrm{w} / \mathrm{v})$ for $60 \mathrm{~min}$ at $37^{\circ} \mathrm{C}$ as described elsewhere [12]. After filtration through a nylon mesh $(250 \mu \mathrm{m})$, the cells were gently washed four times in fresh medium. Insulin binding was performed essentially as described by Gammeltoft and Gliemann [13]. Briefly, cells constituting an approximate volume fraction of $5 \%$ were incubated at $37^{\circ} \mathrm{C}$ and $\mathrm{pH} 7.4$ for $60 \mathrm{~min}$ in medium 199 in the presence of $4 \%$ bovine albumin and monocomponent ${ }^{125} \mathrm{I}$-insulin $(0.13 \mathrm{nmol} / \mathrm{l}$, specific activity about $190 \mu \mathrm{Ci} / \mu \mathrm{g})$. Glucose was present at $5.6 \mathrm{mmol} / 1$ to maintain the cellular ATP levels in the presence of catecholamine [10], and bacitracin $(1 \mathrm{mg} / \mathrm{ml})$ was added to minimize proteolysis. After the appropriate incubation period, cells and medium were separated by centrifugation through silicone oil. Nonspecific binding was corrected by subtracting the binding obtained in the pres- ence of $7 \mu \mathrm{mol} / \mathrm{l}$ unlabelled insulin. For recently discussed reasons [14] no attempt was made to calculate the absolute number of insulin receptors. Reduced binding with a Scatchard plot parallel to that of the control group and unchanged apparent $K_{D}$, calculated as the concentration of unlabelled insulin required to obtain half-maximal tracer binding, was considered to be due to a reduced receptor number. The method used to determine the urinary adrenaline and noradrenaline excretion was a modification of the method described by von Euler and Lishajko [15]. VMA was assayed according to the method of Wisser and Stamm [16]. The normal reference intervals for the laboratory are given in Table 1.

\section{Materials}

Glucagon-poor insulin was generously supplied by Eli Lilly and Co. (Indianapolis, Ind., USA). Medium 199 was obtained from Statens Bakteriologiska Laboratorium (Stockholm, Sweden). Collagenase (type I), propranolol, timolol, isoproterenol and bovine albumin were from Sigma Chemical Co. (St. Louis, Mo., USA). D-propranolol and metoprolol were kindly provided by Dr. B. Åblad, AB Hässle, Gothenburg, Sweden. ${ }^{125} \mathrm{I}$-monocomponent insulin was a generous gift from Dr. S. Ivarsson, Malmö, Sweden and adenosine deaminase was obtained from Boehringer Mannheim, FRG. 

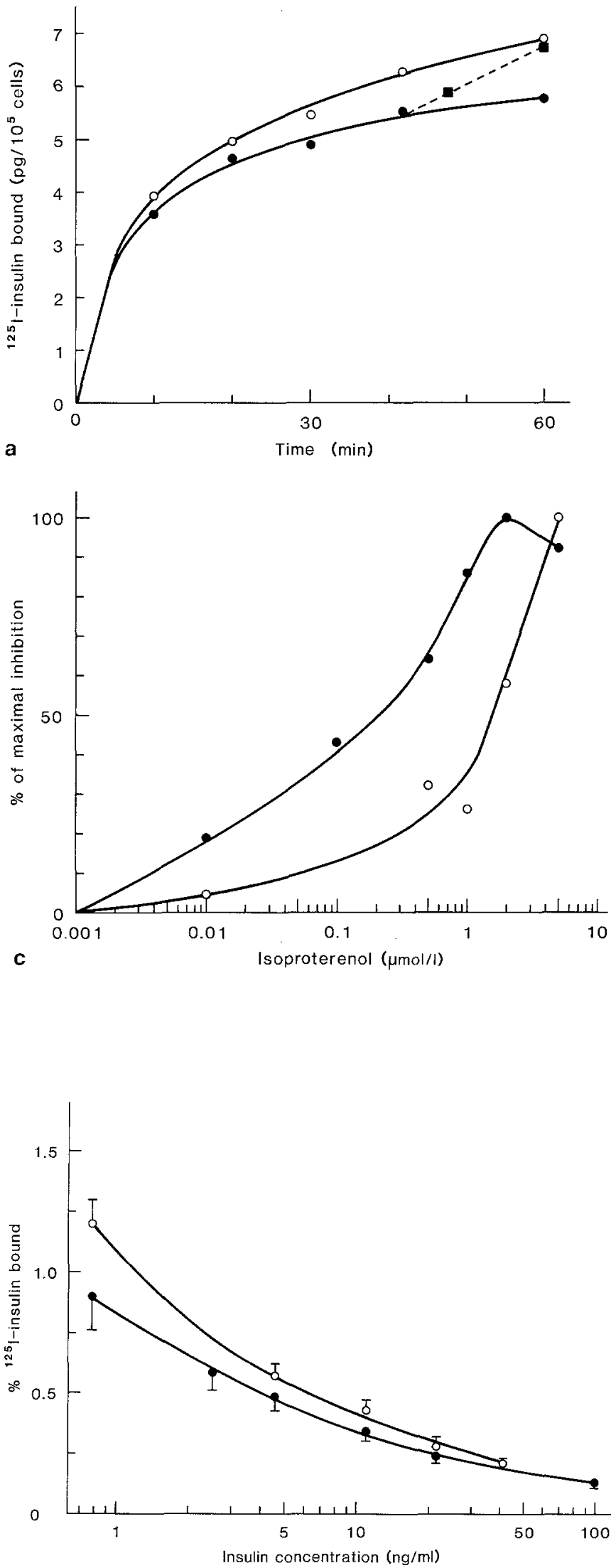

Fig.2. Specific insulin binding to human adipocytes from 6 patients with a phaeochromocytoma $(\longrightarrow$ ) and 16 age- and weightmatched control subjects $(\mathrm{O}-\mathrm{O})$. Results are means \pm SEM. Total insulin binding was significantly $(p<0.05)$ less in the fat cells from the patients with a phaeochromocytoma

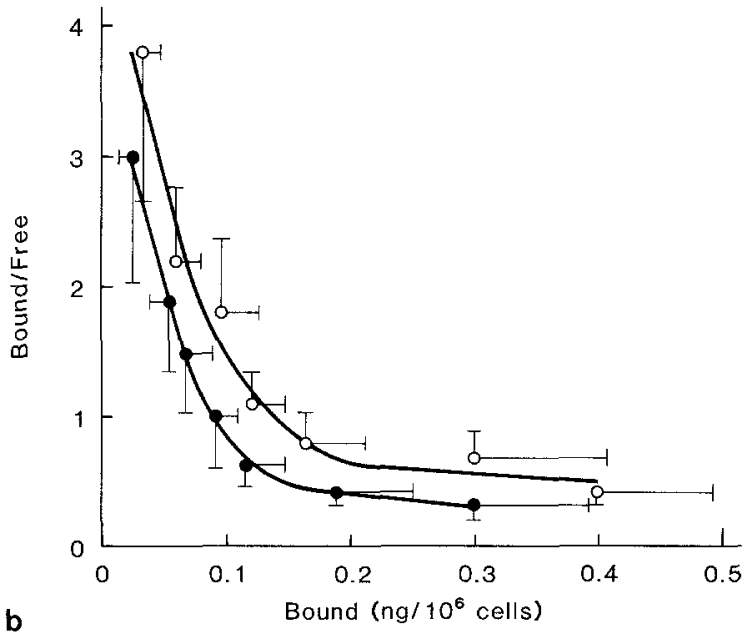

Fig. 1 a. Time course for ${ }^{125} \mathrm{I}$-insulin binding $(0.13 \mathrm{nmol} / \mathrm{l})$ to human adipocytes in the absence $(\mathrm{O}-\mathrm{O})$ ) or presence $(-\infty)$ ) of isoproterenol $\left(10^{-6} \mathrm{~mol} / \mathrm{l}\right)$. Non-specific binding was the same in both incubations. Propranolol $\left(10^{-5} \mathrm{~mol} / \mathrm{l}\right)$ was added after $40 \mathrm{~min}$ to parallel isoproterenol-containing tubes, and insulin binding was measured (a--- Results are means of 3 representative experiments. b Specific insulin binding to human adipocytes after preincubation for $30 \mathrm{~min}$ in the absence $(\mathrm{O}-\mathrm{O}$ ) or presence $(--$ ) of isoproterenol $\left(10^{-6} \mathrm{~mol} / \mathrm{l}\right)$. During the insulin binding assay the same catecholamine concentration was maintained in the incubation medium. Results are means \pm SEM of 4 experiments. Total insulin binding was significantly $(p<0.01)$ less in the presence of isoproterenol. $\mathbf{c}$ The effect of different concentrations of isoproterenol on ${ }^{125} \mathrm{I}$-insulin binding. Isoproterenol, ${ }^{125} \mathrm{I}$-insulin $(0.13 \mathrm{nmol} / \mathrm{l})(\mathrm{O}-\mathrm{O})$ and adenosine deaminase $(2 \mathrm{mU} / \mathrm{ml})(-)$, were added at time zero and insulin binding measured after $60 \mathrm{~min}$. Data are the means of two experiments

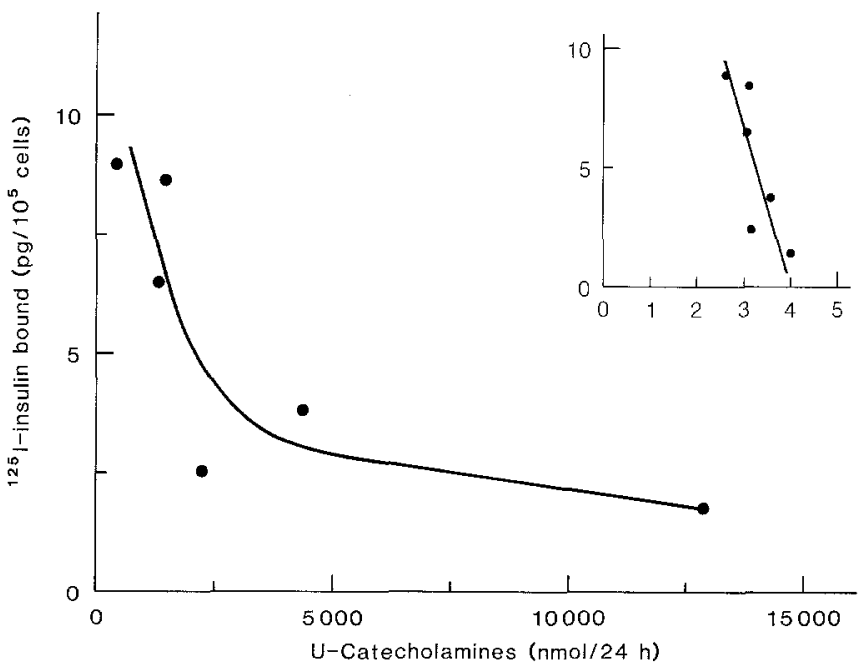

Fig. 3. The relationship between total urinary catecholamine excretion and ${ }^{125} \mathrm{I}$-insulin binding to adipocytes from 6 patients with a phaeochromocytoma $\left(r_{s}=-0.886, p<0.05\right)$. The inserted figure shows the linear correlation between the log of urinary catecholamine excretion and insulin binding $(y=24.7-5.9 x ; \mathrm{r}-0.821, p<0.05)$ 


\section{Statistics}

Statistical significance was tested with the paired or non-paired Student's t-test. Correlation coefficients were calculated according to the least squares method and, where applicable, the Spearman correlation test $\left(r_{s}\right)$ was used.

\section{Results}

The effect of isoproterenol $\left(10^{-6} \mathrm{~mol} / \mathrm{l}\right)$ on insulin binding to human fat cells is shown in Figure $1 \mathrm{a}$. Insulin binding was rapidly decreased and a new steady state established after about $30 \mathrm{~min}$. However, when propranolol $\left(10^{-5} \mathrm{~mol} / \mathrm{l}\right)$ was added to the incubation medium after a 40 -min exposure to isoproterenol, insulin binding was fully restored within $20 \mathrm{~min}$; the halfmaximal effect was reached after about $10 \mathrm{~min}$. Propranolol had no effect on cells incubated in the absence of catecholamine nor did it change the non-specific binding (data not shown).

The specific insulin binding to cells preincubated with isoproterenol $\left(10^{-6}\right)$ for $30 \mathrm{~min}$ is shown in Figure $1 \mathrm{~b}$. As seen in the Scatchard plots, isoproterenol reduced specific binding without producing any obvious change in receptor affinity. Also the apparent $K_{D}$ was similar in cells incubated in the presence or absence of isoproterenol $(0.64 \pm 0.07$ and $0.65 \pm 0.11 \mathrm{nmol} / 1 \mathrm{re}-$ spectively, means \pm SEM). Thus, the reduced binding following isoproterenol exposure is mainly due to a decreased number of binding sites ( $\sim 30 \%$ reduction). Cells incubated with $1 \mathrm{mmol} / \mathrm{l} \mathrm{db}$ cAMP also showed a similar reduction in insulin binding (not shown).

The dose-response relationship between the isoproterenol concentration and inhibition of ${ }^{125} \mathrm{I}$-insulin binding after $60 \mathrm{~min}$ is shown in Figure $1 \mathrm{c}$. Some of these incubations were performed in the presence of adenosine deaminase. The deaminase was included in order to eliminate the interaction of adenosine in the incubation medium. Adenosine is known to reduce the inhibitory effect of catecholamines on both insulin binding and glucose transport in rat fat cells [9-11]. The catecholamine concentration required for half-maximal inhibition of insulin binding was about $150 \mathrm{nmol} / 1$. In the absence of the deaminase the dose-response curve for isoproterenol was shifted fivefold to the right.

An attempt was also made to more specifically study the catecholamine effect and to eliminate a potential interaction with insulin. Short-term preincubations were performed with isoproterenol alone, and insulin binding was measured after the cells had been treated with $2 \mathrm{mmol} / 1 \mathrm{KCN}$ for $5 \mathrm{~min}$. Several previous studies have shown that the membrane protein translocation processes are energy-dependent and are effectively stopped by respiratory inhibitors [17-19].

The effect of pretreating the cells with isoproterenol $(0.5 \mu \mathrm{mol} / 1)$ for $5 \mathrm{~min}$ on insulin binding using this procedure is shown in Table 2 . When the catecholamine effect was unopposed by insulin, this short preincuba- tion period with isoproterenol was sufficient to demonstrate a consistent reduction of insulin binding $(\sim 20 \%)$. This reduction was completely prevented by different $\beta$-adrenoceptor antagonists. However, the inactive isomer, d-propranolol, was without effect. Taken together, these findings show that the effect of catecholamine on insulin binding is rapidly induced and exerted through $\beta$-adrenoceptors.

Specific insulin binding to fat cells from patients with a phaeochromocytoma and their appropriately matched controls is shown in Figure 2. A decreased binding was found in the patients with the catecholamine-producing tumour as compared to the controls $(\sim 30 \%)$. The decreased binding was again due to a reduction of the number of binding sites as the apparent $\mathrm{K}_{\mathrm{D}}$ was similar in both groups $(\sim 0.87 \mathrm{nmol} / 1)$.

In two patients, sufficiently large adipose tissue samples were obtained to perform incubations with and without $20 \mu \mathrm{mol} / 1$ propranolol. However, propranolol was not able to increase the binding in these cells (data not shown).

The relationship between mean diurnal urinary catecholamine excretion and insulin binding to cells from patients with a phaeochromocytoma is shown in Figure 3. A close, non-linear inverse relationship between catecholamine excretion and insulin binding is evident $\left(r_{\mathrm{s}}=-0.886, p<0.05\right)$. When the catecholamine excretion was transformed to a logarithmic scale, a linear negative correlation was found between this parameter and insulin binding (Figure 3, inset; $r=-0.821$, $p<0.05$ ). No significant correlation was found in this group of patients between fasting blood glucose levels and urinary catecholamine excretion, nor between insulin binding and fasting glucose levels.

\section{Discussion}

This study demonstrates the effect of catecholamines on rapidly reducing the number of insulin binding sites in human cells. This finding is similar to recent results with rat adipocytes where catecholamines, via a $\beta$-adrenergic mechanism, rapidly reduced insulin binding [6-8].

A clear inhibitory effect by catecholamines was seen already after $5 \mathrm{~min}$. This reduction was not due to $\mathrm{pH}$ changes in the medium or accumulation of metabolites like FFA since it was rapidly reversed by the addition of propranolol or other specific $\beta$-adrenoceptor blocking agents to the same medium. In agreement with our previous results with rat adipocytes [6], the decreased insulin binding was mainly due to an apparent reduction of the number of receptors. This finding is somewhat at variance with the results of Pessin et al. [7] and Kirsch et al. [8], who attributed the decreased binding to affinity changes or a decreased number of high affinity sites. In a recent study with human adipocytes, Arner et al. [20] reported that high isoproterenol concentrations $(6 \mu \mathrm{mol} / \mathrm{l})$ reduced the affinity of binding sites in the 
absence of glucose in the incubation medium. This effect was prevented by the addition of glucose to the incubation medium. Surprisingly, it was also reported that the effect of glucose was temperature-dependent [20].

The reason for the different interpretations of the catecholamine effect is not clear. However, recent studies have shown the difficulties involved in separating affinity and number changes of recycling membrane proteins in conventional binding assays. In an interesting study, Wardzala et al. [19] showed that insulin increased the affinity of the IGF II binding sites in conventionally incubated fat cells. However, when the recycling processes were stopped by treating the cells with $\mathrm{KCN}$ for $5 \mathrm{~min}$ after the preincubation period with insulin, an increased number of binding sites with an unchanged affinity was seen. The relevance of this latter effect was verified in fractionated cell preparations [19].

The patients with a phaeochromocytoma were exposed to high catecholamine levels in vivo as demonstrated by the markedly elevated urinary catecholamine excretion. It should also be noted that blood glucose levels were reduced postoperatively in all patients but one, whose tumour was not radically operated since she had persistently high catecholamine excretion at a followup study 7 months later. Histological examination of the tumour from this patient showed tumour growth into the capsule, suggesting malignant development.

An inverse correlation could be demonstrated between insulin binding and the urinary catecholamine excretion in the phaeochromocytoma patients. This finding probably reflects a direct casual relationship as shown by the effect of catecholamines added in vitro to fat cells from normal subjects. The attenuation in insulin binding in the patients with a phaeochromocytoma ranged from a slight effect to a $62 \%$ reduction as compared to the appropriately matched control group. For the group as a whole, however, insulin binding was reduced $\sim 30 \%$ due to the large variation in catecholamine secretion from the tumours.

The fact that insulin binding was still reduced in these patients, in spite of the relatively long isolation and preincubation period of the cells in buffer alone (around $90 \mathrm{~min}$ ), shows the persistent effect of longterm catecholamine exposure. Similar findings were also seen in rat fat cells after several hours of exposure to catecholamines in vitro [6]. In order to further characterize the catecholamine effect after long-term exposure, insulin binding was studied in cells from two patients with a phaeochromocytoma with and without the addition of propranolol to the binding assay. Despite the addition of the beta-blocking agent, insulin binding did not increase in these patients (see Fig. $1 \mathrm{a}$ for comparison). Thus, it may well be that long-term $\beta$-adrenergic stimulation, both in vitro and in vivo, leads to a longlasting reduction of insulin binding.

$\beta$-adrenergic stimulation does not only reduce insulin binding and insulin-stimulated glucose transport, but it also reduced EGF and insulin-stimulated IGF II binding [7,21]. The reduction of glucose transport is, in part, due to an inhibition of the insulin-induced translocation of glucose transporters from the intracellular pool to the plasma membrane [10]. Taken together, these data show that the translocation of several membrane proteins in response to insulin is rapidly antagonized by $\beta$-adrenergic stimulation and elevated cAMP levels. This makes it tempting to speculate that cAMP may play an important role in the cellular translocation processes. It is also well-recognized that both the insulin receptor and the EGF and IGF II receptors undergo autophosphorylation [22-24]. At present, it is unknown if the state of phosphorylation of the insulin receptor or other phosphoproteins influences the recycling process discussed above.

Insulin binding did not correlate with fasting blood glucose levels in the patients with a phaeochromocytoma. This is not surprising, however, since the effect of catecholamines on glucose levels in vivo is probably due to several actions such as an $\alpha$-mediated inhibition of insulin secretion [25], increased hepatic glucose production [26] and reduced peripheral insulin sensitivity and responsiveness $[2,3]$. In this context, it should also be noted that insulin levels were similar before and after surgery. This was probably due to the treatment of the patients with $\alpha$-blockade prior to the operation. Thus, the downregulation of insulin binding cannot be attributed to differences in ambient insulin levels.

In conclusion, the present study documents the importance of catecholamines for both acute and longterm regulation of insulin binding. Of particular importance was the finding that the magnitude of the catecholamine effect was concentration-dependent. In the phaeochromocytoma patients with the highest catecholamine excretion, insulin binding was reduced by $50-60 \%$. Such a marked reduction in insulin binding may completely account for the pronounced rightward shift in the dose-response curve for the effect of insulin on peripheral glucose uptake that we have recently observed in healthy controls during catecholamine infusion [3].

Acknowledgements. This work was supported by grants from Swedish Medical Research Council, the Swedish Diabetes Association, Nordisk Insulin Fond, and Göteborgs Läkaresällskap. The excellent technical assistance of A. Johansson is highly appreciated. We are greatly indebted to H.Carlsten, K. Mühlenbock and A.-B. Nordvi for excellent secretarial work.

\section{References}

1. Sacca L, Vigorito C, Cicala M, Ungaro B, Sherwin RS (1982) Mechanism of epinephrine-induced glucose intolerance in normal humans. J Clin Invest 69 : 284-293

2. Deibert DC, DeFronzo RA (1980) Epinephrine-induced insulin resistance in man. $\mathbf{J}$ Clin Invest $65: 717-721$

3. Lager I, Attvall S, von Schenck H, Smith U (1985) Adrenaline-induced insulin resistance in man is a $\beta_{2}$-adrenergic effect. Diabetes 34 (Suppl 1): 54A 
4. Kono T, Barham FW (1971) The relationship between the insulin binding capacity of fat cells and the cellular response to insulin. J Biol Chem 246: 6210-6216

5. Kahn CR (1978) Insulin resistance, insulin insensitivity and insulin unresponsiveness: a necessary distinction. Metabolism (Suppl 2) 27: 1893-1902

6. Lönnroth P, Smith U (1983) Beta-adrenergic dependent downregulation of insulin binding in rat adipocytes. Biochem Biophys Res Commun 112: 972-979

7. Pessin JE, Gitomer W, Oka Y, Oppenheimer CL, Czech MP (1983) $\beta$-adrenergic regulation of insulin and epidermal growth factor receptors in rat adipocytes. J Biol Chem 258: 7386-7394

8. Kirsch DM, Baumgartner M, Deufel T, Rinninger F, Kemmler W, Häring HU (1983) Catecholamine-induced insulin resistance of glucose transport in isolated rat adipocytes. Biochem J 216: $737-745$

9. Green A (1983) Catecholamines inhibit insulin-stimulated glucose transport in adipocytes in the presence of adenosine deaminase. FEBS Lett 152: 261-263

10. Smith U, Kuroda M, Simpson IA (1984) Counter-regulation of stimulated glucose transport by catecholamines in the isolated rat adipose cell. J Biol Chem 259: 8758-8763

11. Davies J, Lönnroth P, Smith U (1985) The kinetics of the insulin, catecholamine and adenosine interaction in the regulation of adipocyte glucose transport. Biochem Soc Trans (in press)

12. Smith U, Sjöström L, Björntorp P (1972) Comparison of two methods to determine human adipose cell size. J Lipid Res 13: $822-824$

13. Gammeltoft S, Gliemann J (1973) Binding and degradation of ${ }^{125} \mathrm{I}-$ insulin by isolated rat fat cells. Biochim Biophys Acta 320: 16-32

14. Pedersen $O(1983)$ Insulin receptor assays used in human studies: Merits and Limitations. Diabetes Care 6: 301-309

15. von Euler US, Lishajko F (1959) The estimation of catecholamines in urine. Acta Physiol Scand 45: 122-132

16. Wisser H, Stamm D (1970) Untersuchungen zur Bestimmung der 4-Hydroxy-3-Methoxymandelsäure (Vannilinmandelsäure) im Urin. J Clin Biochem 8: 21-26

17. Kono T, Robinson FW, Sarver JA, Vega FV, Pointer RH (1976) Actions of insulin in fat cells: effects of low temperature, uncouplers of oxidative phosphorylation, and respiratory inhibitors. J Biol Chem 252: 2226-2233
18. Suzuki K, Kono T (1979) Internalization and degradation of fat cell-bound insulin: separation and partial characterization of subcellular vesicles associated with iodoinsulin. J Biol Chem 254: 9786-9794

19. Wardzala LJ, Simpson IA, Rechler MM, Cushman SW (1984) Potential mechanism of the stimulatory action of insulin on insulinlike growth factor II binding to the isolated rat adipose cell. J Biol Chem 259: 8378-8383

20. Arner P, Hellmér J, Ewerth S, Östman J (1984) Effect of glucose on beta-adrenergic induced downregulation of insulin receptor binding in human fat cells. Biochem Biophys Res Commun 122: 97-102

21. Lönnroth $\mathrm{P}$, Rechler M, Apell K, Smith U (1985) $\beta$-adrenergic stimulation inhibits the insulin-stimulated translocation of the IGFII receptor. Diabetes 34 (Suppl 1): 225 a (Abstract)

22. Kasuga M, Karlsson FA, Kahn CR (1982) Insulin stimulates the phosphorylation of the 95,000 -Dalton subunit of its own receptor. Science 215: 185-187

23. Cohen S, Carpenter G, King L Jr (1980) Epidermal growth factorreceptor-protein kinase interactions. J Biol Chem 255: 4834-4842

24. Hammerman MR, Gavin JR (1984) Binding of insulin-like growth factor II and multiplication-stimulating activity-stimulated phosphorylation in basolateral membranes from dog kidney. J Biol Chem 259: 13511-13517

25. Robertson RP, Porte D Jr (1973) Adrenergic modulation of basal insulin secretion in man. Diabetes 22:1-8

26. Sacca L, Morrone G, Cicala M, Corso G, Ungaro B (1980) Influence of epinephrine, norepinephrine, and isoproterenol on glucose homeostasis in normal man. J Clin Endocrinol Metab 50: 680-684

Received: 6 May 1985

and in revised form: 30 September 1985

Dr. Peter Lönnroth

Department of Medicine II

Sahlgren's Hospital

S-413 45 Gothenburg

Sweden 